\title{
ESTIMASI SINTESIS PROTEIN MIKROBIA RUMEN MENGGUNAKAN EKSKRESI DERIVAT PURIN DALAM URIN DENGAN TEKNIK SPOT SAMPLING PADA KAMBING BLIGON DAN KAMBING KEJOBONG
}

\section{ESTIMATION OF RUMEN MICROBIAL PROTEIN SYNTHESIS BASED ON PURINE DERIVATIVES IN THE URINE USING SPOT SAMPLING TECHNIQUE ON BLIGON AND KEJOBONG GOATS}

\author{
Dianestu Putra ${ }^{1 *}$, Lies Mira Yusiati ${ }^{2}$, dan Ristianto Utomo ${ }^{2}$ \\ ${ }^{1}$ PT. Legiri Makmur Sentosa, Mojosongo, Boyolali, 57351 \\ ${ }^{2}$ Fakultas Peternakan, Universitas Gadjah Mada, Yogyakarta, 55281
}

Submitted: 25 August 2016, Accepted: 5 October 2016

\section{INTISARI}

Penelitian ini bertujuan untuk mengetahui korelasi antara kadar derivat purin (DP) spot sampling dengan ekskresi DP total pada kambing Bligon dan kambing Kejobong. Selain itu, penelitian ini juga bertujuan mengetahui waktu pengambilan sampel yang tepat untuk dapat memprediksi sintesis protein mikrobia pada kedua bangsa kambing tersebut. Ternak yang digunakan adalah kambing Bligon dan kambing Kejobong jantan, masing-masing 6 ekor dengan umur 8 sampai 14 bulan dan berat badan awal sekitar 16 sampai $21 \mathrm{~kg}$ yang ditempatkan pada kandang metabolisme. Jerami kacang tanah sebagai pakan tunggal dan air minum diberikan secara ad libitum. Penelitian meliputi periode adaptasi selama 14 hari, dan periode koleksi selama 3 hari. Selama periode koleksi dilakukan koleksi pakan, sisa pakan, dan feses yang akan dianalisis untuk menentukan kadar bahan kering dan bahan organik. Koleksi urin secara spot sampling maupun koleksi total harian, dilakukan saat ternak diberikan pakan secara ad libitum selama tiga hari. Koleksi sampel untuk metode spot sampling dilakukan dengan pengambilan urin secara periodik dengan interval waktu 3 jam dalam sehari semalam (24 jam). Sampel urin yang didapat dianalisis kandungan creatinine dan DP yang meliputi allantoin, asam urat, xanthin, dan hypoxanthin. Kemudian data yang diperoleh diuji korelasi antara kadar DP urin spot sampling dengan ekskresi total DP. Berdasarkan penelitian diketahui bahwa kadar DP dan creatinine ( $\mu \mathrm{mol} / \mathrm{L}$ ) pada kambing Bligon masing-masing sebesar 1.418,40 dan 202,85, sedangkan pada kambing Kejobong masing-masing sebesar 1.547,40 dan 219,68. Ekskresi total DP, allantoin, asam urat, xanthin dan hypoxanthin serta creatinine ( $\left.\mu \mathrm{mol} / \mathrm{W}^{0,75} / \mathrm{hari}\right)$ pada kambing Bligon berturut-turut sebesar 114,14, 95,86, 17,31, 0,97 dan 16,40, dengan efisiensi sintesis protein mikrobia sebesar 4,61 $\mathrm{g} \mathrm{N} / \mathrm{kg}$ bahan organik yang terfermentasi dalam rumen (DOMR), sedangkan pada kambing Kejobong berturut-turut sebesar 180,18, 158,17, 20,60, 1,40 dan 24,87, dengan efisiensi sintesis protein mikrobia sebesar 6,90 g N/kg DOMR. Berdasarkan penelitian juga diketahui waktu spot sampling terbaik untuk menentukan ekskresi total DP pada kambing Bligon yaitu pada rentang pukul 11.00 hingga 14.00 dengan persamaan $Y=1,474 X+48,81$, sedangkan kambing Kejobong pada rentang pukul 14.00 hingga 17.00 dengan persamaan $Y=2,678 X+5,692$.

(Kata kunci: Ekskresi derivat purin, Kambing Bligon, Kambing Kejobong, Spot sampling)

\section{ABSTRACT}

This study were aimed to determine the correlation between concentration of purine derivatives (PD) in spot sample with PD total excretion in Bligon and Kejobong goats and determine the appropriate sampling time, in order to predicting microbial protein synthesis in both breeds. Six male Bligon goats and six male Kejobong goats with age range from 8 to 14 months and body weight from 16 to $21 \mathrm{~kg}$ were placed in metabolism cages. Peanut straw and water were given to both groups of goats through ad libitum feeding and drinking. The study was done in 14 days for adaptation, 3 days for collection. Sample of feeds, feed residues, and feces were collected and then analyzed to determine dry matter and organic matter content. Spot urine and the total daily urine samples were also collected. Samples collection of spot sampling technique was run by taking the urine periodically with 3 hours intervals at 24 hours. Urine samples were analyzed for the content of creatinine and PD which includes allantoin, uric acid, xanthine, and hypoxanthine. Data were tested for the correlation between concentration of PD spot urine sample with total $P D$ daily excretion. It is known that the concentration of $P D$ and creatinine $(\mu \mathrm{mol} / \mathrm{L})$ for Bligon were $1,418.40$ and 202.85 respectively, while for Kejobong were $1,547.40$ and 219.68 respectively. Total excretion of PD,

\footnotetext{
* Korespondensi (corresponding author):

Telp. +62 8139153 7412, E-mail: dianestuputra@yahoo.com
} 
allantoin, uric acid, xanthyne and hypoxanthine and creatinine ( $\mu$ mol/ $W^{0,75} /$ day) for Bligon were 114.14, 95.86, 17.31, 0.97, and 16.40 respectively, with microbial protein synthesis efficiency was $4.61 \mathrm{~g} \mathrm{~N} / \mathrm{kg}$ degraded of organic matter in rumen (DOMR). Total excretion of PD allantoin, uric acid, xanthyne and hypoxanthine and creatinine ( $\mu \mathrm{mol} / \mathrm{W}^{0,75} /$ day) for Kejobong were 180.18, 158.17, 20.60, 1.40, and 24.87 respectively, with microbial protein synthesis efficiency was $6.90 \mathrm{~g} \mathrm{~N} / \mathrm{kg}$ DOMR. Based on this study also known that the best time for spot sampling to determine the total excretion of PD in Bligon was in the range time of 11.00 am to $2.00 \mathrm{pm}$, with equation $Y=1.474 X+48.81$, while Kejobong goat in the range of 2.00 to $5.00 \mathrm{pm}$, with equation $Y=2.678 X+5.692$.

(Key words: Bligon goat, Kejobong goat, Purine derivative, Spot sampling)

\section{Pendahuluan}

Ternak ruminansia membutuhkan protein yang cukup untuk memenuhi kebutuhan hidupnya. Salah satu sumber protein bagi ruminansia didapatkan dari protein mikrobia yang merupakan produk fermentasi di dalam rumen. Mengingat hal tersebut, perlu dilakukan studi tentang kontribusi mikrobia dalam menyediakan protein bagi ternak inangnya. Pengukuran kontribusi mikrobia, dapat diukur menggunakan metode in vivo yang dilengkapi dengan penggunaan penanda (Givens et al., 2000; Csapo et al., 2001). Metode in vivo diketahui memiliki kelemahan karena memerlukan ternak kanulasi, sehingga kurang praktis dan tidak sejalan dengan animal welfare, maka dibutuhkan penerapan metode lain. Salah satunya yaitu menggunakan metode ekskresi total derivat purin (DP), yang diekskresikan dalam urin selama 24 jam (Givens et al., 2000).

Metode penentuan ekskresi DP ini telah banyak dilakukan untuk menentukan sintesis protein mikrobia rumen dan kontribusinya pada ternak inang, antara lain oleh Belenguer et al. (2002); Mota et al. (2008); Ruiz et al. (2004a); Ruiz et al. (2004b); dan Astuti dan Wina (2002). Mereka meneliti ekskresi DP kambing. Barbosa et al. (2011) dan Braga et al. (2012) meneliti ekskresi DP pada sapi Nellore, kemudian George et al. (2006) dan Singh et al. (2007) meneliti ekskresi DP pada sapi crossbred, sedangkan Chizzotti et al. (2008) dan Kazemi-Bonchenari et al. (2011) pada sapi perah, serta Yusiati (2005) pada sapi PO, sapi Bali, sapi PFH, dan kerbau.

Metode penentuan DP dalam urin, membutuhkan koleksi urin total selama 24 jam. Hal ini dirasa kurang aplikatif, sehingga diperlukan metode yang lebih praktis, yaitu penentuan DP secara spot sampling. Dengan demikian urin tidak dikoleksi selama 24 jam, namun dikoleksi secara spot pada jam tertentu yang dianggap berkorelasi dengan koleksi total. Teknik spot sampling membutuhkan kadar creatinine urin yang dikombinasikan dengan kadar DP, dalam bentuk rasio DP : creatinine dan lazim disebut purine derivative-creatinine index (PDC index).

Derivat purin diketahui merupakan hasil metabolisme dari basa purin dalam tubuh ternak. Setiap spesies maupun bangsa ternak memiliki kecenderungan melakukan proses metabolisme yang berbeda. Hal ini disebabkan karena faktor genetis ternak tersebut yang berbeda. Tak terkecuali ternak ruminansia yang ada di Indonesia. Yusiati (2005) menyatakan bahwa perbedaan genus, spesies maupun bangsa ternak, akan menunjukkan perbedaan ekskresi DP. Hal ini melatarbelakangi penelitian ini untuk mengetahui perbandingan ekskresi DP antara dua bangsa kambing yang berbeda, yaitu Bligon dan Kejobong. Mengingat kambing Bligon dan Kejobong merupakan komoditi ternak yang potensial dikembangkan, serta merupakan kekayaan ragam ternak kambing Indonesia yang sepatutnya dilestarikan.

Kambing Bligon dan Kejobong merupakan dua bangsa kambing yang berbeda bangsa, sehingga memiliki genetis yang berbeda pula. Diketahui bahwa kambing Bligon merupakan persilangan antara kambing Kacang dan Ettawa, dengan daerah pengembangan kambing relatif telah menyebar di kawasan Jawa tengah seperti Kabupaten Brebes, Tegal, Pekalongan (Prawirodigdo et al., 2008) dan Blora (Utomo et al., 2005). Kambing Kejobong diduga merupakan persilangan kambing Kacang dengan Benggala yang diseleksi secara turun temurun di daerah Purbalingga Jawa Tengah, sehingga menghasilkan keseragaman warna tubuh hitam (Astuti et al., 2007). Perbedaan genetis kedua bangsa kambing tersebut, dan didukung perbedaan lingkungan asal kedua bangsa kambing tersebut memiliki potensi pengaruh pada proses pencernaan, termasuk sintesis protein mikrobia rumen. 
Oleh karena itu, diperlukan studi tentang kontribusi protein mikrobia rumen bagi ternak inangnya melalui metode estimasi penentuan DP secara spot sampling, dengan membandingkan antara kedua bangsa kambing tersebut. Sehingga diharapkan dengan adanya penelitian ini, dapat dijadikan sebagai acuan dalam usaha mengoptimalkan kontribusi protein mikrobia terhadap ternak inangnya. Pada akhirnya penelitian ini diharapkan berguna dalam meningkatkan produktivitas ternak, dan akan mendukung pelestarian ragam kekayaan ternak kambing Indonesia.

\section{Materi dan Metode}

Penelitian dilaksanakan selama tujuh bulan mulai bulan September 2013 sampai Maret 2014 di Laboratorium Biokimia Nutrisi dan Kandang Bagian Nutrisi Makanan Ternak, Fakultas Peternakan, Universitas Gadjah Mada.

\section{Materi}

Dalam penelitian ini digunakan 6 ekor kambing Bligon dan 6 ekor kambing Kejobong jantan, umur 8-14 bulan, berat badan $\pm 20,33$ kg untuk kambing Bligon, dan $\pm 17,17$ kg untuk kambing Kejobong. Pakan yang diberikan adalah jerami kacang tanah tanpa akar dalam bentuk segar secara ad libitum. Bahan-bahan yang digunakan untuk analisis laboratorium yaitu kemikalia untuk analisis proksimat, analisis kadar DP, dan creatinine.

Alat-alat yang digunakan dalam penelitian ini terdiri dari kandang metabolis yang dilengkapi dengan tempat pakan dan minum, serta tempat penampung urin dan feses, oven dan tanur untuk uji bahan kering (BK) dan bahan organik (BO), serta inkubator dan spectrofotometer untuk uji DP dan creatinine.

\section{Metode}

Periode adaptasi. Pada periode adaptasi, ternak ditimbang untuk mendapatkan data berat badan yang digunakan sebagai dasar untuk menentukan kebutuhan pakan. Pakan dan minum diberikan dua kali sehari pada pagi hari jam 9.00 dan sore hari pada jam 16.00 secara ad libitum. Periode adaptasi berlangsung selama 14 hari, selama pemeliharaan dilakukan pencatatan jumlah pakan yang diberikan dan sisa pakan, untuk memastikan konsumsi harian ternak telah mencapai ad libitum.

Periode koleksi. Pada periode koleksi yang berlangsung selama 3 hari, ternak diberi pakan dan minum sama seperti pada saat periode adaptasi. Setiap hari selama periode koleksi dilakukan koleksi pakan, sisa pakan, dan feses. Sampel pakan diambil setiap pagi dan sore, sesuai dengan waktu pemberian pakan dengan proporsi yang tetap setiap harinya.

Setiap pagi hari, pakan yang tersisa ditimbang, kemudian diambil sampel dari sisa pakan tersebut dalam jumlah yang proporsional $10 \%$ dari total sisa pakan harian pada tiap ternak. Feses yang diekskresikan selama 24 jam ditampung dalam wadah, kemudian dibersihkan dari pengotor, lalu ditimbang dan diambil sampelnya sebanyak $10 \%$ proporsional terhadap jumlah feses harian, sampel feses selanjutnya disimpan dalam refrigerator. Sampel feses harian tiap ternak yang terkumpul selama periode koleksi dikomposit, kemudian diambil sub-sampel. Terhadap sampel pakan, sisa pakan, dan feses dilakukan analisis BK dan BO yang ditentukan secara gravimetris (AOAC, 2005).

Urin koleksi total yang dieskresikan selama 24 jam, ditampung dalam wadah penampung yang telah diisi dengan $\mathrm{H}_{2} \mathrm{SO}_{4}$ $10 \%$ dengan volume $10 \%$ dari total urin, atau sampai pH kurang atau sama dengan 3. Urin yang telah terkumpul diukur volumenya, lalu disaring untuk menghilangkan kontaminan dalam urin. Hasil saringan kemudian dimasukkan dalam botol dan siap untuk disimpan dalam refrigerator.

Urin koleksi spot sampling ditangani dengan cara yang sama dengan urin koleksi total. Urin koleksi spot sampling didapatkan melalui pengambilan urin secara periodik dengan interval waktu 3 jam dalam sehari semalam (24 jam), yaitu pukul 08.00 sampai $11.00,11.00$ sampai $14.00,14.00$ sampai $17.00,17.00$ sampai $20.00,20.00$ sampai 23.00, 23.00 sampai $02.00,02.00$ sampai 05.00, dan 05.00 sampai 08.00.

Terhadap sampel urin spot sampling maupun urin koleksi total, dilakukan pengukuran kadar DP meliputi allantoin secara spectrofotometric, begitu juga xanthin dan hypoxanthin secara spectrofotometric dengan metode enzimatis (Chen dan Gomez, 1995) serta asam urat (Anonim, 2013). Data kadar DP digunakan untuk menghitung total 
ekskresi DP, dengan cara mengalikan kadar DP dengan volume urin yang diekskresikan.

\section{Analisis data}

Data kadar dan total ekskresi DP yang meliputi allantoin, asam urat, xanthin dan hypoxanthin serta creatinine dan total volume urin, dibandingkan antara kambing Bligon dan Kejobong dengan uji beda mean menggunakan uji Independence sampling T-test (Astuti, 1980).

Data kadar DP dan creatinine dalam urin spot sampling yang diambil setiap 3 jam, dianalisis dengan menghitung rasio DP : Creatinine (DP : C) dalam bentuk PDC index.

$$
\text { PDC index }=\frac{[D P]}{[\text { creatinine }]} \times \mathrm{W}^{0,75}
$$

W adalah berat badan (kg), [DP] dan [ceatinine] merupakan konsentrasi derivat purin dan creatinine (mmol/L) (Chen dan $\varnothing$ rskov, 2003). PDC index atau rasio DP : C hasil perhitungan, kemudian diuji korelasi regresi dengan ekskresi DP dari urin koleksi total.

\section{Hasil dan Pembahasan}

\section{Kadar derivat purin dan creatinine dalam urin}

Kadar allantoin, asam urat, xanthin dan hypoxanthin, DP, serta creatinine ( $\mu \mathrm{mol} / \mathrm{l})$ pada kambing Bligon yang diberi pakan jerami kacang tanah tidak berbeda secara nyata dengan kambing Kejobong $(\mathrm{P}<0,05)$. Rerata kadar allantoin, asam urat, xanthin dan hypoxanthin, DP, creatinine, serta total volume urin yang diekskresikan oleh kambing Bligon dan Kejobong disajikan pada Tabel 1.

Diketahui bahwa faktor yang mempengaruhi kadar DP di antaranya yaitu pakan yang dikonsumsi (Astuti dan Wina, 2002), sumber energi dan protein pakan serta imbangan ketersediaannya dalam rumen (Andrade-Montemayor et al., 2009), senyawa metabolit sekunder semisal tannin (Ruiz et al., 2004a). Perlu diketahui bahwa kambing Bligon dan Kejobong merupakan dua kambing yang berbeda bangsa, sehingga juga dapat mempengaruhi kadar DP. Pemberian pakan yang sama pada kedua bangsa kambing bertujuan agar tidak terdapat potensi perbedaan DP yang disebabkan karena faktor pakan. Oleh karena itu, apabila terdapat perbedaan kadar DP, merupakan pencerminan perbedaan kedua bangsa kambing. Namun demikian, hasil analisis data menunjukkan tidak terdapat perbedaan kadar DP dan senyawa penyusunnya antara kedua bangsa kambing tersebut. Meskipun demikian, bukan berarti hal tersebut serta merta mencerminkan kesamaan tingkat sintesis protein mikrobia pada kedua bangsa kambing, karena untuk mengetahui sintesis protein mikrobia perlu diketahui total ekskresi DP, yang merupakan perkalian antara kadar DP dan volume urin yang diekskresikan.

Di sisi lain, kadar creatinine dalam urin tidak dipengaruhi oleh pakan yang dikonsumsi, melainkan dipengaruhi oleh berat badan ternak (Kertz et al., 1970; George et al., 2006). Mengingat hal tersebut, dapat dipahami bahwa kadar creatinine kedua bangsa kambing menunjukkan kesamaan, disebabkan kedua bangsa kambing yang digunakan pada penelitian ini memiliki rentang berat badan yang homogen.

Berdasarkan Tabel 1, diketahui bahwa total volume urin harian yang diekskresikan oleh kedua bangsa kambing tidak menunjukkan perbedaan yang nyata, namun diketahui bahwa volume ekskresi urin kambing Kejobong cenderung lebih tinggi daripada kambing Bligon. Volume urin yang dieksresikan oleh kambing dipengaruhi oleh beberapa faktor, di antaranya yaitu cara pemberian air minum, tingkat konsumsi air minum (Abdelatif et al., 2010), status fisiologis semisal fase laktasi (Basheir et al., 2009), serta musim dan temperatur lingkungan (ElNouty et al., 1990).

\section{Ekskresi total derivat purin dan creatinine}

Ekskresi total allantoin, asam urat xanthin dan hypoxanthin, DP, serta creatinine, pada kambing Bligon dan Kejobong dalam $\mu \mathrm{mol} / \mathrm{ekor} /$ hari maupun dalam satuan berat badan metabolik ( $\mu \mathrm{mol} / \mathrm{W}^{0,75} /$ hari), disajikan pada Tabel 2.

Berdasarkan Tabel 2, diketahui ekskresi allantoin ( $\mu$ mol/ekor/hari) kambing Kejobong secara nyata lebih tinggi daripada kambing Bligon $(P<0,05)$, namun ekskresi allantoin yang telah dikoreksi dengan berat badan metabolik pada kambing Bligon tidak berbeda secara nyata dengan kambing Kejobong. Ekskresi asam urat, xanthin dan hypoxanthin serta creatinine baik dalam $\mu \mathrm{mol} / \mathrm{ekor} / \mathrm{hari}$ maupun $\mu \mathrm{mol} / \mathrm{W}^{0,75} / \mathrm{hari}$, pada kambing Bligon tidak berbeda secara nyata dengan kambing Kejobong. Namun demikian, ekskresi total DP kambing Kejobong secara nyata lebih tinggi daripada kambing 
Tabel 1. Rerata kadar allantoin, asam urat, xanthin dan hypoxanthin, DP, creatinine, serta total volume urin pada kambing Bligon dan Kejobong

(concentration of allantoin, uric acid, xanthine, hypoxanthine, $P D$, creatinine, and total urine volume of Bligon and Kejobong goat)

\begin{tabular}{|c|c|c|}
\hline \multirow[t]{2}{*}{ "Kadar $(\mu \mathrm{mol} / \mathrm{l})($ concentration $(\mu \mathrm{mol} / \mathrm{l}))$} & \multicolumn{2}{|c|}{ Kambing (goats) } \\
\hline & Bligon & Kejobong \\
\hline Allantoin ${ }^{\text {ns }}$ & $1.178,41 \pm 104,68$ & $1.335,94 \pm 103,51$ \\
\hline Asam urat (uric acid) ${ }^{\text {ns }}$ & $227,90 \pm 35,09$ & $197,96 \pm 15,34$ \\
\hline Xanthin dan hypoxanthin (xanthine dan hypoxanthine) $)^{\mathrm{ns}}$ & $12,08 \pm 1,60$ & $13,53 \pm 1,60$ \\
\hline Derivat purin $\left(\right.$ purine derivatives) $^{\text {ns }}$ & $1.418,40 \pm 88,71$ & $1.547,40 \pm 106,64$ \\
\hline Creatinine $^{\text {ns }}$ & $202,85 \pm 44,12$ & $219,68 \pm 30,82$ \\
\hline${ }^{*}$ Total volume urin (urine volume) ${ }^{\mathrm{ns}}$ & $788,50 \pm 88,87$ & $960,22 \pm 171,80$ \\
\hline
\end{tabular}

* dalam $\mathrm{ml} /$ hari (in $\mathrm{ml} /$ day).

Bligon $(P<0,05)$ baik dalam $\mu$ mol/ekor/hari maupun maupun setelah dikoreksi dengan berat badan metabolik ( $\mu \mathrm{mol} / \mathrm{W}^{0,75} /$ hari).

Perbedaan ekskresi DP antara kedua bangsa kambing meskipun dengan perlakuan pakan yang sama, memperlihatkan bahwa perbedaan bangsa antara kambing Bligon dan Kejobong yang menyebabkan perbedaan ekskresi DP tersebut. Hasil yang serupa dinyatakan Yusiati (2005) yang melaporkan bahwa perbedaan bangsa pada sapi PO, sapi Bali dan sapi PFH, menghasilkan ekskresi DP yang berbeda. Hasil ini sejalan dengan Purwati et al. (2013) yang melaporkan bahwa bangsa kambing Kejobong menghasilkan DP yang lebih tinggi daripada kambing Bligon.

Nelson dan Cox (2008) menjelaskan bahwa proses metabolisme tubuh melibatkan enzim, sedangkan enzim tersusun utamanya oleh protein, dan diketahui sintesis protein ditentukan oleh material genetis DNA. Oleh karena itu dapat dimengerti bahwa perbedaan genetis antara kambing Bligon dan kambing Kejobong akan berpengaruh pada metabolisme dalam tubuh, termasuk metabolisme purin, yang akan berakibat pada perbedaan ekskresi DP. Pengaruh genetis kedua bangsa ternak nampaknya didukung oleh kondisi pakan maupun lingkungan asal Hasil DP penelitian ini dapat digunakan untuk menghitung estimasi sintesis protein mikrobia rumen dengan menggunakan persamaan $Y=0,84 X+\left(0,150 W^{0.75} e^{-0.25 X}\right) \quad$ yang dikembangkan oleh Chen dan Gomes (1995), dengan mensubtitusikan DP endogen dalam persamaan tersebut, dengan DP endogen kambing Bligon dan Kejobong hasil penelitian Purwati et al. (2013). Berdasarkan persamaan

Tabel 2. Ekskresi total allantoin, asam urat, xanthin dan hypoxanthin, derivat purin serta creatinine pada kambing Bligon dan Kejobong

(total excretion of allantoin, uric acid, xanthine, hypoxanthine, purine derivatives, and creatinine of Bligon and Kejobong goat)

\begin{tabular}{|c|c|c|}
\hline \multirow[t]{2}{*}{ Ekskresi (excretion) } & \multicolumn{2}{|c|}{ Kambing (goats) } \\
\hline & Bligon & Kejobong \\
\hline \multicolumn{3}{|l|}{ Dalam $\mu \mathrm{mol} / \mathrm{ekor} / \mathrm{hari}$ (in $\mu \mathrm{mol} / \mathrm{head} / \mathrm{day}$ ) } \\
\hline Allantoin (allantoin) & $917,26 \pm 117,54^{a}$ & $1.325,60 \pm 257,26^{\mathrm{b}}$ \\
\hline Asam urat (uric acid) ${ }^{\text {ns }}$ & $165,92 \pm 15,82$ & $174,81 \pm 26,49$ \\
\hline Xanthin dan hypoxanthin (xanthine dan hypoxanthine) $)^{\mathrm{ns}}$ & $9,22 \pm 0,97$ & $11,63 \pm 1,17$ \\
\hline Derivat purin (purine derivatives) & $1.092,40 \pm 118,91^{\mathrm{a}}$ & $1.512,00 \pm 282,06^{b}$ \\
\hline Creatinine (creatinine) $)^{\mathrm{ns}}$ & $156,60 \pm 34,85$ & $209,98 \pm 49,49$ \\
\hline \multicolumn{3}{|l|}{ Dalam $\mu \mathrm{mol} / \mathrm{W}^{0,75} /$ hari (in $\mu \mathrm{mol} / \mathrm{W}^{0.75} /$ day) } \\
\hline Allantoin (allantoin) ${ }^{\mathrm{ns}}$ & $95,86 \pm 11,82$ & $158,17 \pm 29,44$ \\
\hline Asam urat (uric acid) ${ }^{\text {ns }}$ & $17,31 \pm 1,54$ & $20,60 \pm 2,70$ \\
\hline Xanthin dan Hypoxanthin (xanthine dan hypoxanthine) $)^{\mathrm{ns}}$ & $0,97 \pm 0,11$ & $1,40 \pm 0,16$ \\
\hline Derivat purin (purine derivatives) & $114,14 \pm 11,90^{\mathrm{a}}$ & $180,18 \pm 32,02^{b}$ \\
\hline Creatinine (creatinine) $)^{\mathrm{ns}}$ & $16,40 \pm 3,65$ & $24,87 \pm 5,38$ \\
\hline
\end{tabular}


tersebut dapat ditentukan jumlah DP yang terserap dalam intestine. Hasil DP terserap digunakan untuk menghitung sintesis protein mikrobia dengan persamaan (EMNS, g/d) = $(\mathrm{X} \mathrm{mmol} / \mathrm{d} \times 70) /(0,83 \times 0,116 \times 1000)=0,727 \mathrm{X}$.

Estimasi sintesis protein mikrobia kambing Bligon yang diberi pakan jerami kacang tanah pada penelitian ini sebesar 0,825 g N/hari. Kambing Kejobong yang diketahui menghasilkan DP yang lebih besar daripada kambing Bligon, menunjukkan sintesis protein mikrobia sebesar 1,221 g $\mathrm{N} /$ hari. Data sintesis protein mikrobia rumen kemudian dapat digunakan untuk menentukan efisiensi sintesis protein mikrobia, dengan membagi hasil estimasi sintesis protein mikrobia dengan bahan organik tercerna yang terfermentasi dalam rumen (DOMR). Nilai DOMR dapat ditentukan dengan mengalikan bahan organik tercerna dengan 0,65 (Chen dan Gomes, 1995). Berdasarkan penelitian ini diketahui bahwa efisiensi sintesis protein mikrobia pada kambing Bligon sebesar 4,61 g N/kg DOMR, sedangkan pada kambing Kejobong sebesar $6,90 \mathrm{~g} \mathrm{~N} / \mathrm{kg}$ DOMR. Mbewe et al. (2014) melaporkan bahwa perbedaan pakan dapat menunjukkan perbedaan sintesis protein mikrobia pada kambing, bahkan pada saat tingkat konsumsi pakan yang sama.

Korelasi kadar DP urin koleksi spot sampling dengan ekskresi DP total koleksi

Penentuan korelasi dilakukan dengan membuat regresi linear antara ekskresi DP urin total koleksi dengan rasio kadar DP : creatinine (PDC index) pada masing-masing urin koleksi spot sampling (selama 24 jam). Hal ini dilakukan untuk mencari korelasi terkuat antara kadar DP urin spot sampling dengan ekskresi DP urin koleksi total. Data korelasi pada masing-masing waktu spot sampling disajikan pada Tabel 3 (kambing Bligon) dan Tabel 4 (kambing Kejobong).

Analisis regresi linear antara kadar DP urin spot sampling dan ekskresi DP urin koleksi total pada kambing Bligon pada umumnya menunjukkan korelasi yang rendah, namun demikian pada koleksi spot sampling jam ke 11.00 hingga 14.00 diketahui memiliki korelasi yang paling tinggi dengan koleksi urin total.

Hasil penelitian ini berbeda dengan hasil penelitian Yusiati (2005) yang menyatakan bahwa korelasi terkuat kadar DP urin spot sampling dengan urin total koleksi pada sapi Bali adalah pada pagi hari dengan rentang waktu 7.00 hingga 10.00. Apabila dikaji lebih mendalam, akan lebih lengkap jika rentang waktu spot sampling dikaitkan dengan waktu pemberian pakan. Hal ini mengingat pendapat Chen et al. (1992) dan George et al. (2006) yang menyatakan bahwa terdapat variasi konsentrasi DP dalam satu hari. Variasi konsentrasi DP ini dapat disebabkan karena variasi diurnal absorbsi purin mikrobia pada usus yang disebabkan frekuensi makan ternak, sehingga akan lebih baik apabila waktu spot sampling juga diperhitungkan berdasarkan waktu pemberian pakan.

Apabila dikaitkan waktu koleksi spot sampling dengan waktu pemberian pakan, diketahui bahwa waktu spot sampling yang memiliki korelasi yang signifikan dengan koleksi harian pada kambing Bligon adalah pada rentang waktu 2 hingga 5 jam setelah pemberian pakan pagi hari.

Analisis regresi antara kadar DP urin spot sampling dan urin koleksi total pada

Tabel 3. Korelasi antara rasio kadar DP : creatinine urin spot sampling dengan ekskresi DP pada urin koleksi total kambing Bligon

(corelation betwen purin derivatives : creatinine ratio and urinary purine derivatives total excretion of Bligon goat)

\begin{tabular}{lcccc}
\hline \hline $\begin{array}{c}\text { Waktu spot sampling } \\
\text { (sampling time) }\end{array}$ & $\begin{array}{c}\text { N perlakuan } \\
\text { (replication) }\end{array}$ & $\mathrm{P}$ & $\mathrm{R}^{2}$ & $\begin{array}{c}\text { Persamaan linear regresi } \\
\text { (linear regretion equation) }\end{array}$ \\
\hline $08.00-11.00$ & 6 & $>0,05$ & 0,007 & $\mathrm{Y}=0,065 \mathrm{X}+110,1$ \\
$11.00-14.00^{\star *}$ & 6 & $<0,05$ & 0,876 & $\mathrm{Y}=1,474 \mathrm{X}+48,81$ \\
$14.00-17.00$ & 6 & $>0,05$ & 0,089 & $\mathrm{Y}=0,453 \mathrm{X}+90,19$ \\
$17.00-20.00$ & 6 & $>0,05$ & 0,004 & $\mathrm{Y}=0,135 \mathrm{X}+107,9$ \\
$20.00-23.00$ & 6 & $>0,05$ & 0,042 & $\mathrm{Y}=-0,219 \mathrm{X}+125,6$ \\
$23.00-02.00$ & 6 & $>0,05$ & 0,706 & $\mathrm{Y}=1,794 \mathrm{X}+32,42$ \\
$02.00-05.00$ & 6 & $>0,05$ & 0,006 & $\mathrm{Y}=-0,030 \mathrm{X}+116,0$ \\
$05.00-08.00$ & 6 & $>0,05$ & 0,124 & $\mathrm{Y}=-0,088 \mathrm{X}+125,2$ \\
\hline
\end{tabular}


Tabel 4. Korelasi antara rasio kadar DP : creatinine urin spot sampling dengan ekskresi DP pada urin koleksi total kambing Kejobong

(corelation betwen purin derivatives : creatinine ratio and urinary purine derivatives total excretion of Kejobong goat)

\begin{tabular}{lcccc}
\hline \hline $\begin{array}{c}\text { Waktu spot sampling } \\
\text { (sampling time) }\end{array}$ & N perlakuan (replication) & $\mathrm{P}$ & $\mathrm{R}^{2}$ & $\begin{array}{c}\text { Persamaan linear regresi } \\
\text { (linear regretion equation) }\end{array}$ \\
\hline $08.00-11.00$ & 6 & $>0,05$ & 0,171 & $\mathrm{Y}=0,251 \mathrm{X}+147,8$ \\
$11.00-14.00$ & 6 & $>0,05$ & 0,628 & $\mathrm{Y}=-0,357 \mathrm{X}+225,6$ \\
$14.00-17.00^{\star *}$ & 6 & $<0,01$ & 0,940 & $\mathrm{Y}=2,678 \mathrm{X}+5,692$ \\
$17.00-20.00^{*}$ & 6 & $<0,05$ & 0,793 & $\mathrm{Y}=2,955 \mathrm{X}-11,12$ \\
$20.00-23.00^{\star *}$ & 6 & $<0,01$ & 0,927 & $\mathrm{Y}=2,351 \mathrm{X}+9,916$ \\
$23.00-02.00$ & 6 & $>0,05$ & 0,136 & $\mathrm{Y}=0,700 \mathrm{X}+135,3$ \\
$02.00-05.00$ & 6 & $>0,05$ & 0,001 & $\mathrm{Y}=0,061 \mathrm{X}+176,9$ \\
$05.00-08.00$ & 6 & $>0,05$ & 0,334 & $\mathrm{Y}=-0,236 \mathrm{X}+211,2$ \\
\hline
\end{tabular}

** signifikan $(P<0,01)($ significant at $(P<0.01))$.

* signifikan $(P<0,05)$ (significant at $(P<0.05))$.

kambing Kejobong umumnya menunjukkan korelasi yang rendah, namun berdasarkan tabel dapat diketahui bahwa terdapat tiga waktu spot sampling yang memiliki korelasi signifikan dengan yang terdapat pada urin koleksi harian $(\mathrm{P}<0,01)$. Adapun waktu-waktu tersebut yaitu pada sore hari pukul 14.00 hingga 17.00, 17.00 hingga 20.00, serta pada malam hari pukul 20.00 hingga 23.00. Namun demikian, diantara tiga waktu koleksi spot sampling pada penelitian ini, diketahui bahwa koleksi spot sampling pada rentang waktu 14.00 hingga 17.00 memiliki korelasi terkuat.

Apabila dikaitkan waktu spot sampling dengan waktu pemberian pakan, diketahui bahwa waktu spot sampling pada kambing Kejobong yang memiliki korelasi signifikan dengan koleksi total adalah pada rentang 5 hingga 14 jam setelah pemberian pakan pagi hari dan pada rentang 0 hingga 7 jam setelah pemberian pakan sore hari.

George et al. (2006) menjelaskan bahwa konsentrasi DP yang dibandingkan dengan creatinine memiliki korelasi yang signifikan pada koleksi sampel 0 dan 6 jam setelah pemberian pakan, sedangkan menurut Dipu et al. (2006), rentang waktu spot sampling yang memiliki korelasi yang signifikan yaitu 12 jam setelah pemberian pakan. Apabila ditelaah, dapat dikatakan bahwa rentang waktu spot sampling dengan korelasi terkuat pada kambing Bligon senada dengan pernyataan George et al. (2006). Di lain sisi, waktu spot sampling dengan korelasi terkuat pada kambing Kejobong berada pada kisaran hasil yang dinyatakan oleh George et al. (2006) maupun Dipu et al. (2006).

\section{Kesimpulan}

Berdasarkan data yang diperoleh dari penelitian ini, dapat diambil kesimpulan bahwa ekskresi total DP kambing Kejobong lebih tinggi dari pada kambing Bligon. Berdasarkan penelitian ini juga diketahui bahwa terdapat perbedaan rumus persamaan regresi dan waktu spot sampling terbaik antara kedua bangsa kambing. Diketahui bahwa waktu spot sampling terbaik kambing Bligon pada rentang pukul 11.00 hingga 14.00 dengan persamaan regresi $Y=1,474 X+48,81$, sedangkan kambing Kejobong pada rentang waktu 14.00 hingga 17.00 dengan persaman regresi $Y=2,678 X+5,692$.

\section{Ucapan Terima Kasih}

Pada kesempatan ini dengan kerendahan hati, penulis menyampaikan penghargaan dan terima kasih yang sebesarbesarnya kepada Prof. Dr. Ir. Ali Agus, DAA., DEA., selaku Dekan Fakultas Peternakan Universitas Gadjah Mada yang telah memberikan kesempatan penulis dalam mengikuti pendidikan. Prof. Dr. Ir. Lies Mira Yusiati, SU., selaku pembimbing utama dan Prof. Dr. Ir. Ristianto Utomo, SU., selaku pembimbing pendamping, serta seluruh dosen Fakultas Peternakan Universitas Gadjah Mada yang telah memberikan bimbingan, arahan serta dukungan. Beasiswa Fast track DIKTI, atas diberikannya beasiswa sehingga penulis dapat melanjutkan studi Pasca Sarjana S-2. 


\section{Daftar Pustaka}

Anonim. 2013. Fluitest Uric Acid. Analyticon ${ }^{\circledR}$ Biotechnologies AG. Lichtenfels.

AOAC. 2005. Official Method of Analysis of the Association of Official Analitycal Chemists. $18^{\text {th }}$ edn. AOAC International. William Harwitz (ed). United States of America, Maryland.

Abdelatif, A. M., Salwa, A. Elsayed and Y. M. Hassan. 2010. Effect of state of hydration on body weight, blood constituents and urine excretion in nubian goats (Capra hircus). World J. Agric. Sci. 6: 178-188.

Andrade-Montemayor, H., T. G. Gasca and J. Kawas. 2009. Ruminal fermentation modification of protein and carbohydrate by means of roasted and estimation of microbial protein synthesis. R. Bras. Zootec. 38: 277291.

Astuti, D. A. and E. Wina. 2002. Protein balance and excretion of purine derivatives in urine of lactating Etawah Crossbred goats fed with tempe waste. Seminar Nasional Teknologi Peternakan dan Veteriner.

Astuti, M. 1980. Statistik. Bagian Pemuliaan Ternak Fakultas Peternakan Universitas Gadjah Mada, Yogyakarta.

Astuti, M., A. Agus, I. G. S. Budisatria, B. Aryadi, L. M. Yusiati, dan M. A. U. Muzayyanah. 2007. Peta Potensi Plasma Nutfah Ternak Nasional. Ardana Media, Yogyakarta.

Barbosa, A. M., R. F. D. Valdares, S. C. V. Filho, D. S. Pina, E. Detmann and M. I. Leao. 2011. Endogenous fraction and urinary recovery of purine derivatives obtained by different methods in Nellore Cattle. J. Anim. Sci. 89: 510519.

Basheir, R. A., S. A. Omer and O. S. A. Mohamed. 2009. Effect of lactation on some urine indices of renal functionin Nubian goats. J. Sci. Tech. 10: 1-8.

Belenguer, A., D. Yanez, J. Balcells, N. H. O. Baber and M. Gonza'lez-Ronquillo. 2002. Urinary excretion of purine derivatives and prediction of rumen microbial outflow in goats. Livest. Prod. Sci. 77: 127-135.

Braga, J. M. D. S., R. F. D. Valadares, S. G. Pellizzoni, S. C. V. Filho, L. L. Prates and L. F. C. Silva. 2012. Estimation of endogenous contribution and urinary excretion of purine derivatives from the total digestible nutrient intake in Nellore heifers. R. Bras. Zootec. 41: 18991906.

Chen, X. B. and E. R. Ørskov. 2003. Research on urinary excretion of purine derivatives in ruminant: Past present and future. International Feed Resources Unit. Macaulay Land Use Research Institute, Craigiebuckler, Aberdeen.

Chen, X. B. and M. J. Gomes. 1995. Estimation of microbial protein supply to sheep and cattle based on urinary excretion of purine derivatives. An overview of the technical details. Rowett Research Institute, Bucksburn. Aberdeen.

Chen, X. B., G. Grubic, E. R. Ørskov and P. Osuji. 1992. Effect of feeding frequency on diurnal variation in plasma and urinary purine derivatives in steers. Anim. Prod. 55: 185-191.

Chizzotti, M. L., S. C. V. Filho, R. F. D. Valadares, F. H. M. Chizzotti and L. O. Tedeschi. 2008. Determination of creatinine excretion and evaluation of spot urine sampling in Holstein cattle. Livest. Sci. 77: 127-135.

Csapo, Z. C. J., J. Schmidt and T. G. Martin. 2001. Quantitative determination of protein of bacterial origin. Trends in Analytical Chemistry. 20: 42-48.

Dipu, M. T., S. K. George, P. Singh, A. K. Verma and U. R. Mehra. 2006. Measurment of microbial protein supply in murrah buffaloes using urinary purine derivatives excretion and PDC index. Asian-Aust. J. Anim. Sci. 19: 347-355.

El-Nouty, F. D., A. A. Al-Haidary and S. M. Basmeil. 1990. Physiological responses, feed intake, urine volume and serum osmolarity of Aardi goats deprived of water during spring and summer. Asian-Aust. J. Anim. Sci. 3: 331-336.

George, S. K., M. T. Dipu, U. R. Mehra, A. K. Verma and P. Singh. 2006. Influence of level feed intake on concentration of purine derivatives in urinary spot samplings and microbial nitrogen supply in crossbred bulls. Asian-Aust. J. Anim. Sci. 19: 1291-1297.

Givens, D. I., E. Owen, R. F. E. Axford and H. M. Omed. 2000. Forage Evaluation in Ruminant Nutrition. CABI Publishing. 
Kazemi-Bonchenari, M., K. Rezayasdi, H. A. Ghasemi, A. H. Farahani, M. DeghanBanadaky and A. Mahdavi. 2011. Effect of rumen degradable protein suplementation on purine derivatives excreted through urine and milk in lactating Holstein cows. J. Anim. Vet. Adv. 10: 2389-2393.

Kertz, A. F., L. R. Prewitt, A. G. Lane and J. R. Campbell. 1970. Effect of dietary intake on creatinine excretion and the creatinine-nitrogen ratio in bovine urine. J. Anim. Sci. 30: 278-282.

Mbewe, M. R., V. R. Hamandishe, V. E. Imbayarwo-Chikosi and B. Masunda. 2014. Nitrogen balance and rumen microbial protein synthesis in goats fed diets containing soaked and roasted Mucuna bean (Mucuna pruriens). Online J. Anim. Feed Res. 4: 06-09.

Mota, M., J. Balcells, N. H. O. Baber, S. Boluktepe and A. Belenguer. 2008. Modelling purine derivative wxcretion in dairy goats: endogenous excretion and the relationship between deudenal input and urinary output. J. Anim. 2: 4451.

Nelson, D. L. and M. M. Cox. 2008. Principles of Biochemistry. $5^{\text {th }}$ edn. Freeman Publishers, Wisconsins.

Prawirodigdo, S., T. Herawati, dan B. Utomo. 2008. Penampilan peternakan kambing dan potensi bahan pakan lokal sebagai komponen pendukungnya di wilayah Propinsi Jawa Tengah. Balai Pengkajian Teknologi Pertanian Jawa Tengah, Lokakarya Nasional Kambing Potong, pp: 157-163.
Purwati, C. S., L. M. Yusiati, dan S. P. S. Budhi. 2013. Kontribusi ekskresi basal purin terhadap total ekskresi derivat purin dalam urin kambing Bligon dan Kejobong. Buletin Peternakan 37: 6-11.

Ruiz, D. R. Y., A. I. M. Garcia, A. Moumen and E. M. Alcaide. 2004a. Ruminal fermentation and degradation patterns, protozoa population, and urinary purine derivatives excretion in goats and wethers fed diets based on olive leaves. J. Anim. Sci. 82: 3006-3014.

Ruiz, D. R. Y., A. Moumen, A. I. M. Garcia and E. M. Alcaide. 2004b. Ruminal fermentation and degradation patterns, protozoa population, and urinary purine derivatives excretion in goats and wethers fed diets based on two-stage olive cake: Effect of PEG supply. J. Anim. Sci. 82: 2023-2032.

Singh, M., K. Sharma, N. Dutta, P. Singh, A. K. Verma and U. R. Mehra. 2007. Estimation of rumen microbial supply using urinary purine derivatives excretion in crossbred calves fed at different levels of feed intake. AsianAust. J. Anim. Sci. 20: 1567-1574.

Utomo, B., T. Herawati and S. Prawirodigdo. 2005. Productivity of goat farming on rural condition. Seminar Nasional Teknologi Peternakan dan Veteriner, pp: 660-665.

Yusiati, L. M. 2005. Pengembangan metode estimasi sintesis protein mikrobia rumen menggunakan ekskresi derivat purin dalam urin berbagai ternak ruminansia Indonesia. Disertasi. Fakultas Peternakan, Universitas Gadjah Mada, Yogyakarta. 